University of Wollongong

Research Online

Faculty of Business - Papers (Archive)

Faculty of Business and Law

2020

University-led internships for innovative thinking: a theoretical framework

Nadeera Ranabahu

University of Canterbury

Shamika Almeida

University of Wollongong, shamika@uow.edu.au

Elias Kyriazis

University of Wollongong, kelias@uow.edu.au

Follow this and additional works at: https://ro.uow.edu.au/buspapers

Part of the Business Commons

Research Online is the open access institutional repository for the University of Wollongong. For further information contact the UOW Library: research-pubs@uow.edu.au 


\title{
University-led internships for innovative thinking: a theoretical framework
}

\author{
Abstract \\ Purpose - This article explains how business internships can be used to develop innovation skills in \\ undergraduates. Design/methodology/approach - Using work-integrated learning and current literature on \\ innovation, this article proposes a theoretical framework to design, implement, and measure outcomes of \\ Innovation-Focused Internships (IFIs). The article also uses an illustrative case study from an Australian \\ university to discuss practical use of this framework. Findings - The theoretical framework illustrates that \\ stakeholders (i.e., students, industry, and university) need a common goal. Factors associated with \\ managing innovation and student placements are key features of the framework. The illustrative case \\ study demonstrates ways in which students gather both professional work experience and innovative \\ skills. Practical implications - The illustrative case study outlines practical strategies and challenges in IFI \\ programs. Managing innovation-related challenges requires adjustments from all the stakeholders. \\ Originality/value - This article modifies the existing stakeholder interdependency model of work- \\ integrated learning by combining it with innovation-related literature. The novel insights from the IFI \\ program demonstrate how factors associated with students, industry, and university, and associations \\ between these key stakeholders shape and determine IFI success. \\ Disciplines \\ Business

\section{Publication Details} \\ Ranabahu, N., Almeida, S. \& Kyriazis, E. (2020). University-led internships for innovative thinking: a \\ theoretical framework. Education and Training, 62 (3), 235-254.
}




\section{University-led internships for innovative thinking: A theoretical framework}

Purpose: This paper explains how business internships can be used to develop innovation skills in undergraduates.

Design/methodology/approach: Using work-integrated learning and current literature on innovation, this paper proposes a theoretical framework to design, implement, and measure outcomes of Innovation-Focused Internships (IFIs). The paper also uses an illustrative case study from an Australian university to discuss practical use of this framework.

Findings: The theoretical framework illustrates that stakeholders (i.e., students, industry and university) need a common goal. Factors associated with managing innovation and student placements are key features of the framework. The illustrative case study demonstrates ways which students gather both professional work experience and innovative skills.

Originality/value: This paper modifies the existing stakeholder interdependency model of work-integrated learning by combining it with innovation-related literature. The novel insights from the IFI program demonstrate how factors associated with students, industry, and university, and associations between these key stakeholders shape and determine IFI success.

Practical implications: The illustrative case study outlines practical strategies and challenges in IFI programs. Managing innovation-related challenges requires adjustments from all the stakeholders.

Keywords: Internship, work-integrated learning, innovation, university, undergraduates, industry

\section{Introduction}

Work-integrated learning programs (specifically internships) designed by universities can play a crucial role in achieving innovation-related outcomes. An internship includes experiential learning where students are exposed to research, training, and professional environments outside of their university (Fitzgerald et al. 2014). The emphasis is on the 
reinforcement of subject content, real-world relevance, and application of the subject matter (Fitzgerald et al. 2014) where students are given opportunities to combine and integrate different types of knowledge (Eraut et al. 2004). As a result, students learn to apply subject content and solve problems (Fitzgerald et al. 2014; Tsai 2011).

Less often, internships enable students to develop innovative products or processes, build on their ideas, and even create technology-based companies (Galeano et al. 2012). These outcomes are often reported in subjects such as STEM (science, technology, engineering and mathematics) (Starr-Glass 2006), entrepreneurship (Gundry et al. 2014), and marketing (von der Heidt 2018). These outcomes have resulted organically without an explicit aim to improve innovative thinking. However, business internships could do far better by having clear innovation-related goals and designing programs accordingly. This paper addresses this practical issue and explains how to design and implement an Innovation-Focused Internship (IFI) program. This paper answers the research question of: how should a Business faculty design internships to enhance innovation skills of undergraduates?

This paper explains what an IFI program is by combining available definitions of innovation and internships. Innovation is defined as the "management of all the activities involved in the process of idea generation, technology development, manufacturing and marketing of a new (or improved) product or manufacturing process or equipment" (Trott 2017, pp. 15-16). Among students, "research, development, problem solving, leadership, and entrepreneurial skills, along with the capacity to recognize innovation in work contexts" contribute to their innovation literacy (Luke 2013, p.38). An internship is a work-integrated learning technique which uses industry placements to provide students opportunities to apply theory into practice (Burdett and Barker 2017). As a result, students grow both personally and professionally (Burdett and Barker 2017). By combining these two definitions, this paper defines an IFI program as work-integrated 
learning opportunities that allow students to grow personally and professionally by experiencing activities associated with the innovation process within an industry setting.

IFI programs are required due to changes in the current workplace, such as automation of work, changes in employment types, and disruptions in production or distribution of goods in value chains (World Economic Forum 2018). To address these emerging workplace challenges graduates need skills related to analytical thinking, innovation, creativity, critical thinking and problem solving (World Economic Forum 2018). However, the existing internship programs are mainly focused on providing undergraduates with skills related to application of the subject matter into professional work (Fitzgerald et al. 2014). These skills, although currently essential, may not be as useful in the future. This indicates that educators need to design internships with fundamentally different objectives, compared to professional internships, to develop future-ready graduates.

This paper aims to provide a theoretical framework to design, implement and measure outcomes of IFI programs. To do so, this study combines work-integrated learning theories and innovation-related literature. An illustrative case from an Australian university is also used to support the framework. This paper provides new theoretical insights on how factors/characteristics associated with students, industry, and university, and associations between these key stakeholders shape and determine IFI success. Hence, this study contributes: a) theoretically, by developing a framework for IFI design and implementation within university contexts, and b) practically, by providing insights from a case study for IFI design and implementation.

\section{Literature review: Internships}

Stakeholder analysis, based on stakeholder theory, conducted within a university context (Chapleo and Simms, 2010), identifies primary stakeholders engaged in an internship as 
students, university, and industry (Hoyle and Goffnett, 2013; Patrick et al. 2008). These primary stakeholders are embedded in higher education context and operate within the broader government policy framework (Patrick et al. 2008). Professional internships, designed to provide specialist technical/professional knowledge to students, focus on student learning where industry provides the context, and a university outlines parameters of engagement according to graduate attributes they want to develop (de Villiers Scheepers et al. 2018). The university, industry and students are interdependent on each other and managing each of these associations is vital to the success of internships (Patrick et al. 2008). This paper, similar to work of de Villiers Scheepers et al. (2018), Hoyle and Goffnett (2013), and Patrick et al. (2008), uses the stakeholder interdependency approach to develop a framework for IFI program design and implementation.

\section{Factors required for the overall success of an internship}

The success of these internships depends on having common and shared objectives across all the stakeholder groups. For example, industry views an internship as a mutual reciprocal professional activity (Stanley 2017). Yet, some organisations lack clarity regarding what is expected of them (Ferkins 2002) and have unrealistic expectations about graduates' skills (Jackson and Chapman 2012). At the same time, some students expect that an internship would lead to employment at the same company (Silva et al. 2018), while a few are unclear about placement objectives (Ferkins 2002) or do not have the mastery required to use particular software or hardware (Jackson 2015). In fact, the main objective of universities is to provide generic and career-specific work experience aligning with pedagogical approaches (Clark et al. 2016). These multiple and sometimes conflicting objectives can affect the success of an internship.

In an internship, continuous feedback is vital as the industry, students, and universities play flexible roles as teachers, facilitators, and learners (Hodge et al. 2011). The academics coordinating internships obtain feedback from both students and industry. 
Students provide feedback through formal and informal mechanisms such as evaluations, reflections, presentations, surveys, and discussions (Jackson 2015; Kim et al. 2012). Some universities share the final reports of the students with industry while others invite industry representatives to student presentations. The industry provides feedback through formal channels such as intern evaluations or discussions. This continuous feedback assists universities to modify and update courses, as well as/and provide feedback to students on how to gain maximum benefits from their internships (Ferrández-Berrueco et al. 2016), and design authentic case studies, role-plays and scenarios (Jackson 2015). For industry partners, feedback provides an assessment of their workplace and indicates how attractive the workplace is for potential future recruits (Petrillose \& Montgomery 1997). For students, feedback provides valuable insights into their work ethics and practices (Jackson 2015).

\section{Generic skills and capabilities required among student interns}

Students require skills such as communication, time management, teamwork, selfconfidence, and self-motivation to integrate into a professional workplace to complete an internship (Collet and Wyatt 2005; Hurst and Good 2010; Jackson 2015; Khalil 2015). Students should also have the ability to cope with unstructured learning associated with a real work environment (Renganathan et al. 2012); hence, the need to think 'laterally' which often frightens them (Collet and Wyatt 2005). Sometimes interns have to work in relatively physically isolated locations and need the ability to develop networks and establish new contacts in their new location (Holyoak 2013). It is also essential that students have an understanding of their fundamental character strengths and behaviours that enable them to be resourceful when integrating into their workplaces.

Additionally, IFI students should have innovative skills. Innovative behaviour involves combination, integration, and re-contextualisation of different types of knowledge (Evans \& Guile 2012). It also includes the ability to prosper in changing 
environments, understand the nature of any new situation, recognise areas of knowledge relevant to the new situation, focus on types of knowledge needed for decisions or actions, and transform that knowledge to suit new situations and contexts (Brown 2014). According to Dyer et al. (2009), innovative individuals regularly practise five discovery skills to enhance their innovative mind set. These include: a) associating (i.e., the ability to connect seemingly unrelated questions, problems, and ideas from different fields); b) questioning (i.e., the ability to ask questions that challenge the conventional wisdom); c) observing (i.e., the ability to carefully, intentionally, and consistently look for behavioural details among stakeholders to gain insights about new ways of doing things); d) experimenting (i.e., construction of interactive experiences and explorations); and, e) networking (i.e., meeting and interacting with people who have different kinds of ideas and perspectives).

Recently, Luke (2013) examined the innovations skills required and subsequently acquired by college students engaged in applied research projects with small to medium size enterprises (SMEs) in Canada. He used the term 'innovation literacy' to describe the innovation-related skills and capabilities that differentiate these students from those with generic skills. Innovation literacy is the ability to "to think creatively, evaluate, and apply problem solving skills to diverse and intangible issues within industrial problems and multidisciplinary contexts (Luke 2013, p.38). It includes "research, development, problem solving, leadership and entrepreneurial skills"; "an amalgam of skills that encompasses the cognitive, psychomotor and affective domains of learning" (Luke 2013, p.38).

\section{Success factors associated with industry partners}

Industry perception on internships is often associated with the benefits that they can receive (Thatcher et al. 2016; Tudor \& Mendez 2014). For example, a partnership between the University of Cape Town and the South African Coal Oil and Gas Corporation has resulted in human resource, technology and infrastructure development 
benefiting both the parties (Cele 2005). In the University of Calgary, engineering students use technology to find solutions for social problems, which resulted in inventions, including patents, and partnerships with sports franchises (Chang 2016). Hence, the identification of clear, tangible benefits for the industry contributes to a successful internship.

Literature also suggests that generic — common across industries — and industry-specific needs for innovations can play a crucial role. Generic factors include commercial reasons such as the need to grow product portfolios or market share, ability to increase firms' competitive advantage, and need to increase organisational talent pool (Fraser et al. 2011; Thatcher et al. 2016; Yildirim \& Şimşek 2015). Industry-specific reasons for emphasising innovations are driven by economic forces, technological developments, and changing social demographics. For example, in mobiletelecommunications, innovations are essential to cater to the demands of the growing customer base and address mobile data traffic (Althaus 2012). In the construction industry, contractors have to reduce environmental impacts during the construction process; hence, management and technology innovations focused on 'green' construction are emphasised to improve the efficiency of resources usage and protect the environment (Qi et al. 2010). Therefore, IFIs can be highly successful in industries where there is a clear need for innovation.

\section{Success factors associated with universities}

The university (i.e., academics coordinating the program) must be clear about graduate learning outcomes from an internship. The content, design, and structure of the course and the way internships are arranged within study programs need to be planned carefully (Jackson 2015; Silva et al. 2018). This also includes recognising that internships are different from classroom teaching, with regard to curricula and pedagogical approaches (Clark et al. 2016). 
The workload of academics associated with coordinating internships needs to be considered in program design. Typically, undergraduate internships require more direction and support, due to the interns' lack of work experience (Hoyle \& Deschaine 2016). Coordinating internships also involves teaching, administrative, and even pastoral responsibilities (Clark et al. 2016) which increase the workload. Hence, some universities engage the service of 'mentors' such as expert entrepreneurs, industry professionals, or previous interns (Hoyle \& Deschaine 2016; Procter 2012). They can even assist new recruits in filling applications and provide general information about organisations.

The way performance-based outputs of academics are measured affects the longterm success of internships. Flores (2016) states that there should be a new measurement system to determine the effectiveness of industry-university partnerships. The author highlights that, on the one hand, companies do not see universities as business partners and hence the top managers are not motivated to increase collaborations. On the other hand, academics are more interested in publications. Hence, the author proposes the success of university-industry linkage should be measured by new-products/services based on co-development, which are launched into the market. Similarly, internship success should be measured using outcomes such as quantity and quality of industry partnerships, collaborations, and patents, rather than academic publications.

For an IFI to be successful, universities need to benchmark their performance against institutions that have embraced innovation as an organisational mission (e.g., Georgia Institute of Technology), create hubs that foster knowledge exchange with industry, and engage in boundary-spanning activities to impart tacit and codified knowledge to industry stakeholders (Youtie \& Shapira 2008). Universities too, need to develop a culture amongst its students and academics to network, collaborate, and provide opportunities for cross-disciplinary pollination to test, research and prototype their ideas (Eesley \& Miller 2017). At the same time, having a closer look at the existing 
university infrastructure, including networks, available professional placement services and reward structures can facilitate the program implementation.

\section{Successful management of the university-industry association}

It is vital to have a formal agreement between university and industry about the ownership of any intellectual property (Hurn 2016). Although not frequent, students have developed new inventions as a result of internships. Chang (2016) and Mil'Shtein (2010) report that after internships, some students were exploring commercialising opportunities for their inventions such publishing their work, exploring patent options, or soliciting partnerships with sports franchises. Although Mil'Shtein (2010) and Chang (2016) do not explain the process involved, when the university and industry partners discussed and agreed on intellectual rights, Rutherforda and Holmesb (2008) highlight that there could be rifts in university-industry partnership when it comes to intellectual rights.

As long-term collaborations are challenging, engaging industry beyond formal agreements contributes to internship success (Hurn 2016). Walsh and Byrne (2013) explain that industry collaborations need to be nurtured and fostered for long-lasting partnerships and customer retention techniques need to be used by universities to understand employers' needs and retain industry partners. This reduces the time and effort of searching for new organisations for student placements (Walsh \& Byrne 2013). Hence, the placement manager has a crucial role in maintaining industry partnerships as the industry wants to deal with a manager they can trust, who understands their needs, and with whom they can collaborate (Walsh \& Byrne 2013). Also, the industry expects a professional, responsive, efficient placement service that provides accurate information, a clear alignment of students with job specifications and an efficient interview process (Walsh \& Byrne 2013). One way to achieve this is through maintaining interns and industry data appropriately by using web-portals (Neill \& Mulholland 2003). 


\section{Successful management of the university-student association}

The ability of both students and academics to translate theory into practice helps students to adjust to workplaces. It is often viewed that students are unable to apply concepts taught in the class into professional work (Prabhu \& Kudva 2016). This could be due to students' inability to adjust to unstructured informal or incidental learning that occurs in workplaces compared to the structured formal learning at universities (FerrándezBerrueco et al. 2016; Renganathan et al. 2012). This is also partly due to academics not using practical examples and anecdotes from the industry (Prabhu \& Kudva 2016). To avoid this, 'reflexive practices' are encouraged as they compel students to align theoretical material with their daily activities in the workplaces (Ferrández-Berrueco et al. 2016; Jackson 2015; Starr-Glass 2006). In IFI assessments, these reflexive practices need to be grounded on students' innovative skills, in particular on their ability to associate, question, observe, experiment and network (Dyer et al. 2009). However, it may be important that students are provided with some training to develop these skills before the internship, and then develop activities within the internship curriculum that require students to reflect on the use of their innovative skills.

\section{Successful management of the industry-student association}

Industry supervisors play a critical role in achieving learning outcomes (Holyoak 2013;

Hurst et al. 2012; Hurst \& Good 2010). Interns, to cope with work demands, are expected to network and use their experience for learning (Holyoak 2013). However, the 'fit' between interns and supervisors who want to maximise the learning experience for students while balancing their own work pressures, is difficult to achieve (Holyoak 2013). If the students can translate theoretical learning into practice, it helps in managing the 'fit' between the two parties as some organisations view internships as an opportunity to enhance staff mentoring capabilities (Stanley 2017). Nevertheless, interns are often reliant upon one or two key individuals, to make sense of activities, which can be 
frustrating due to the short period students spend on organisations (Holyoak 2013). Particularly when organisations participate in IFIs, it is fundamental that supervisors assigned to interns have capabilities that nurture and support innovative ideas, and facilitate opportunities for networking, and cross-disciplinary idea generation.

\section{Theoretical framework: Successful design and implementation of IFIs}

By incorporating innovation and work-integrated literature into the stakeholder interdependency approach, this paper identifies a combination of factors (student, industry, and university - based) that contributes to the successful design and implementation of an IFI program. As highlighted in the literature review, IFIs, unlike professional internships, should manage both the innovation aspect and the work placement component. The following diagram illustrates this (see Figure 1).

\section{Insert Figure 1 here}

As Figure 1 illustrates, successful design and implementation of IFIs is a holistic effort between students, industry and university. In professional internships, the industry provides a context for students to gather generic and career-specific skills and apply academic knowledge to their professional work (de Villiers Scheepers et al. 2018). In contrast, IFIs attempt to enhance innovative skills among interns, while the industry partner gains a unique perspective, a new process, or a new way of solving problems. Hence, benefits industry partners could achieve, and their need for innovations are key factors determining the program success. At the same time, students having discovery skills associated with innovative thinking and graduate skills associated with integrating into a professional workplace are essential. The university designs programs according to the graduate attributes required and administer IFIs. Hence, policies associated with workload and output measures need to be clearly aligned to support the involvement of academics in the program. 
As Figure 1 illustrates (see the box with double-bold lines), expectations, aims and objectives need to be managed where the same message needs to be communicated to all the stakeholders. Similarly, there should be continuous feedback through formal or informal channels such as student presentations, reflective essays, or formal surveys.

Furthermore, associations between stakeholders are critical for success (denoted by the shaded boxes with a broken line in Figure 1). Industry partners' resource commitment can have a significant positive influence on the students' perceived success of the internship (Hardie et al. 2018) while the degree of translation of the theory into practice determines students' engagement in the internship. An industry engagement manager or internship coordinator usually handles the association between the industry and the university. Having both formal and informal agreements and engagement events can also strengthen the association between the industry and universities.

\section{Illustrative case study: reflective data, analysis and reporting}

To examine the practical application of the above framework, this paper used an IFI program piloted in one of the Australian universities. Academics managed the internship at the Faculty of Business (second and third author of the paper) alongside the regular professional internship. The first author was a member of the tutoring team during the pilot IFI. The teaching team /authors are from a cross disciplinary background a) innovation/entrepreneurship, b) human resource management, and c) marketing and product development.

Autoethnographic techniques were used to collect data, analyse them and report the findings. In some disciplines, autoethonography is considered problematic as 'self' is used to produce data (Holt 2003). Winkler (2018) discusses issues such as the use of 'hard' data vs 'soft' impressions, solo vs collaborative techniques, and ethical issues associated with autoethnography. However, Winkler (2018) also points out that 
challenges associated with autoethnography are often reported in other research approaches as well. The advantage of using autoethnography is that it allows researchers to understand, and question their own beliefs and critically explore teaching practices (Trahar 2013). Reflective practices used in autoethnography provide inputs to promote dialogue on quality enhancement and student experience (Kinchin and Wiley 2018). These can also be used as a means of professional development (Kinchin and Wiley 2018). Hence, by using the autoethnographic technique, authors were able to record, question, critique and refine the IFI program development process and these reflective insights can be useful for other educational practitioners.

Reflective data: The primary data used here are authors' reflections in designing, teaching and evaluating the IFI program. Due to cross disciplinary background of the authors, understanding and reflections were at times dissimilar which made the authors question one another's paradigm of thinking and find new ways of making meaning of their experience of planning, managing and evaluating the success of the pilot program. Thus authors adapted a constructivist based approach that assumes the relativism of multiple social realities, and recognise the importance of mutual creation of knowledge which aims towards an interpretive understanding of our experiences (Charmaz 2006). Following Chang (2008), objective data available about the program, such as student presentations, their assignments and informal feedback, available data about the industry, and industry assessments about the program/students (e.g., media coverage) were also used to make sense. These also assisted to fill in gaps left by the self-based data and validate and correct the personal accounts (Chang 2008).

Reflective \& iterative data collection and analysis process: Each author kept notes separately about students' learning, subject content, feedback, and key literature. These were used as the basis for understanding each other's experience, and for sensemaking within the context. As autoethnographic research process is not linear, where data collection process is often intertwined with data analysis and interpretation (Chang 2008), 
authors' reflective insights about the IFI program occurred in stages followed by periods of planning, reflections, and implementation and further reflections. First, there were informal discussions between the second and third author. Then, a review of literature was conducted by the first author to refine the IFI concept. This helped authors to design and reflect on the best practices. Next, authors' reflective understandings were shaped by the discussions between authors and students, and industry partners, and between the three authors. The industry discussions helped in understanding the context while the student and industry comments and feedback during and after the internship allowed authors to understand the success and challenges of the process. Finally, one year after implementation of the program, detached, objective assessment about the future modifications were conducted by the authors; this also provided further insights. This stage-wise reflection process also demonstrates dynamic interplay between the data collection, analysis and interpretation associated with autoethnography.

When analysing the data, we used our notes, and discussions and compiled similar ideas together. As Chang (2008) point out, this process is equivalent to coding. Then we refined the key ideas. When doing so, authors' considered different possible theoretical explanations, formed possible explanations based on our diverse reflections, as well as student and industry feedback at different stages and then/finally pursued the most plausible explanation (Charmaz 2006).

Ensuring rigour: Following Stahlke Wall (2016), this study ensured rigour by having clear purpose and application for autoethnography, linking experience to existing theory and literature, using of multiple data sources, and ensuring a systematic method was followed. As explained, the purpose of this study was to provide insights into the IFI program development and implementation. There was a clear research question and needs/gaps identified. The study was grounded on innovation and work-integrated literature and used the stakeholder interdependency theoretical approach. Multiple sources were used to generate reflective data and a systematic reflective-iterative data 
collection, analysis and interpretations were used. Therefore, this autoethonographic account of the IFI program provides rigorous and useful insights.

Reporting: Although how to report autoethonographic narratives is still debated (see Chang 2008 and Winkler 2018), this paper, following Chang (2008), combines reflective findings with 'objective' data. Hence, quotes from student presentations, and assignments are used to avoid issues related to reliability. Authors obtained permission from the students to use quotes from their assignments and presentation slides in an anonymised way. In addition from an ethical point of view, to avoid identifying students, due to their association with the authors (Stahlke Wall 2016; Winkler 2018), this paper anonymised both student and industry names.

\section{Application of the stakeholder interdependency approach to an IFI program}

\section{Rationale of the IFI}

The pre-requisite of the IFI was that students should have completed the third-year applied innovation-focussed undergraduate subject. One of the authors of this paper coordinated this third year innovation based product development subject. He had a strong belief that the students who undertake the innovation based subject are well trained in analysing and supporting innovation in organisations. He pitched the idea of an innovation based internship (to be done in the following session) and identified a few students who he considered as potential candidates for the IFI program. He used his

judgement based on student academic performance and personal characteristics such as their drive, motivation and communication capabilities. Much of his observations included in-classroom formal and off -classroom informal student consultations. Many hours were spent outside of formal class time to interact and converse with the students to understand their suitability for he IFI program. Most times, the students were known to 
the coordinator, as he had taught them over several years including a first year Marketing subject.

Then, during the internship, they would enter an organisation as a trained, new products development executive, to work on identified projects. During the internship, students were expected to transfer best practice theory to the organisation, work on a negotiated innovation project, critically audit the innovation processes of the organisation assessing what they thought was useful or not, and suggest possible improvements. A significant component of the IFI was to develop a new product idea or service offering on a new product or service/app. The motivation to provide tangible benefits to the industry was to differentiate IFI program interns with other interns. By positioning IFI program interns as consultants, rather than employees as in professional internships, students are able to discuss industry issues on more equal grounds. It also prevents them from being assigned with routine tasks such as data entry or filing which requires limited or no cognitive effort.

\section{Pre-requisite to be an intern in IFI program}

All the students were carefully selected for the IFI considering their performance in the pre-requisite third-year product development subject (see Table 1 for details).

\section{Insert Table 1 here}

As highlighted in Table 1, during the 3rd year subject, activities were conducted to ensure students' innovation literacy; these included establishing the value proposition of a new product/service, which is not in existence, to an identifiable target group of customers, conducting a full marketplace and competitive analysis to determining product positioning versus potential competitors offerings, forecasting sales, assessing the profitability, and pitching the idea to a hypothetical board of directors (their classmates). This subject ensured that students selected for the IFI program understood the innovation- 
related concepts, and gained an understanding about the skills and capabilities required to be innovative thinkers. Further, IFI students were also required to participate in workshops arranged by the professional internship coordinator to ensure that they are also aware of the professional skills required to integrate into the industry.

\section{Stakeholders and their characteristics}

In the first IFI, six students worked alongside the industry partners (three organisations) and provided innovative marketing solutions.

\section{Insert Table 2 here}

As Table 2 demonstrates, industry partners were from three different sectors. All these industries had a clear need for innovation. For example, the innovation within the aged care service provider (students 1 to 3 ) was driven by changing demographics that required creating a better lifestyle for older people. To do that, the aged care service provider was aiming to develop a grants program to initiate innovations within internal staff and introduce a new, extra services package to its clients. This organisation had a separate innovation committee, and the students worked closely with them. Similarly, students 4 and 5 worked in the manufacturing sector, and the organisation had recently incorporated elements of a digital strategy to their marketing division due to changing use of social media and web-based tools for purchasing. Student 6 worked in an industry where online sales patterns are changing the product-based business model. Hence, manufacturing firms also had a clear need to improve their digital presence to maintain a competitive advantage.

During a reflective conversation between two of the authors, we acknowledged the level of trust we needed to develop with the industry partners. For example, one of the author's had developed a relationship with few of the industry contacts over a period of time, where one was a former student and part of the marketing association in the 
university while the other industry partner relationship was cultivated over a period of time after meeting at a networking session.

The authors worked/work in a regionally based university. The institution focuses on offering personalised and outstanding learning environment and works with industry partners to create greater levels of impact and innovation. Its key strategic goals include addressing regional and international needs, providing exceptional learning and student experience, and celebrating partnerships with stakeholders including the business community. Hence, the IFI program aligns with the overall university strategic direction.

\section{IFI program coordination and assessments}

Two academics, assisted by the tutors and the student work placement team, coordinated the IFI program. The internship subject included: teaching content (resourcefulness and innovative skills and personal strengths, emotional intelligence, support systems), consultation, and tutorials. There was 4 hours of in-class teaching with the other interns and 10 hours allocated for formal consultation with the students to discuss internship and subject assessment expectations, managing ongoing challenges, and student presentations. In addition, there were 4 hours of tutorials where reflective practices were discussed.

The IFI had three academic assessments: a) a scoping document, b) an innovation project presentation of innovation results, and c) a final reflective report that included a completed performance review with the industry supervisor, and a daily activity journal. On reflection, we note how we needed to design the assessments to suit the needs of students but we also needed to ensure the practical aspect of the assessment and its use to the industry partners. This assessment design took place over a period of 6 months and we needed to gain feedback from industry partners and other relevant university personnel to see the validity and the suitability of the assessments. The scoping document 
required interns to provide an initial assessment and justification of the internship organisation's overall new product development process, articulate the specific new product development problem or set of problems that the organisation has asked them to focus on, and to provide an action plan of how they can provide practical solutions. The second assessment, innovation project presentation, required them to present the outcomes of the project. The final report is a reflective essay. To prepare for the essay, students were asked to keep a journal. They were also asked to attach the performance evaluation from their industry supervisor with the report. In addition, interns were also expected to give a presentation to the industry stakeholders.

\section{Shared aims and objectives}

The IFI program had clear objectives of enhancing innovation skills among undergraduates. Aligning with the university strategic objectives, the program aimed to prepare the students for future workplaces. The specific aims of the program were related to identifying a new product development process, enhancing the ability to explain various qualitative and quantitative methods associated with idea generation, concept testing, sales forecasting, product and market testing, improving skills associated with developing a marketing strategy, and understanding the critical factors that can lead to the success or failure of a new product. Having these clear student learning outcomes assisted in designing the internship. At the same time, having these goals assisted in evaluating student tasks using surveys, interviews, and other techniques.

Through the lectures conducted before the internship, students understood that skills associated with innovation, are required for future workplaces. Students also had personal objectives and aims to achieve:

My personal objective at XXX was to learn how to be effective in an innovative professional setting. I was not focused on being in an actual business setting, as I had prior experience with this. Rather, I was interested in ensuring I closely followed XXX's innovative practices and delivered a project that demonstrated 
clear innovative and original thinking. A second goal was to ensure that I matched innovation with clear, undeniable research, as this is a skill I personally pride myself on (An extract from the scoping document: Student 4).

Similarly, the industry had clear objectives of enhancing innovative capabilities within their businesses. For example, the CEO of one of the pilot organisation was interested in new service delivery models:

AAA has recognised innovation as being so critical to our future operations that we have a directorate entirely focused on it-and we are seeing some great work coming together with our new flagship XXX site which is piloting new ways of delivering our services (Media release: CEO of one pilot organisation).

During one of the reflective conversations between the researchers, we acknowledged the amount of time spent on negotiations and discussions with the key industry partners of the IFI. It took several conversations to negotiate and design customised innovation based project for each of the innovation interns. We needed to ensure that all the innovation projects were aligned to the industry partner needs while achieving student learning outcomes. We also needed to be mindful of realistic student capabilities.

\section{Skills and capabilities acquired by students through the IFI program}

IFI program assisted the students to sharpen their professional skills as well as innovation skills. In terms of professional skills, although some students already had skills, internships, as they worked with an industry supervisor, allowed them to sharpen their communication and problem solving skills:

This internship has also provided me [us] with a greater understanding of how to work effectively in a professional workplace. With XXX's guidance, we learnt how to correspond with people above us to discuss our ideas, solve any problems and present the results of our work (Academic Presentation: Students 4 \& 5).

In addition, all students faced time constraints, and they were able to balance work, studies, with personal commitments and manage time.

In terms of innovation skills, students were able to enhance only certain 
elements/aspects of innovation literacy. Students faced challenges, such as unfamiliar work environments (students 3 and 6 ) and lack of understanding about the industry (students 1 and 2 : aged care, student 6: manufacturing). Hence, to deliver project outputs in an unfamiliar environment, students needed to use associating, questioning, observing, experimenting and networking skills. For example, students 1 and 2 sharpened their research skills by studying the aged care industry and that required them to move out of their comfort zone and question and observe. They also applied problem solving skills learnt from general professional work into novel contexts, associated and connected different concepts, and had a certain degree of lateral thinking. Hence, working in an unfamiliar setting and managing challenges helped them to develop skills, related to innovation literacy, that they did not previously have.

Innovation skills were also required by the students to deliver their projects. The projects assigned were relatively difficult with theory and practical components. Hence, students needed to use their discovery skills (such as associating, questioning, experimenting and networking) to deliver the project outputs. These were evident from the students' final presentations where solutions they suggested had some 'novelty' and lateral thinking where they had combined innovation, marketing, strategy with industry specific requirements. However, students' mind-set of considering the projects as challenges appeared to facilitate the discovery process:

The project was intense, difficult, and something far beyond what we had encountered at university - it was a sink or swim moment. We chose to swim! (Academic presentation: Students 1 and 2)

\section{Achieving university-related objectives}

Achieving university related objectives occurred through the implementation of the program. However, academics' role in IFI programs, the way their contribution was measured and recognised, required structural changes to university polices/procedures. For example, although face-to-face contact hours (teaching, tutoring, and consultation) were considered in workload calculations, the workload model for the internship was 
different to other face-to-face delivered subjects. Specifically, the internship included elements such as pre-workshops, mentoring, and industry relationship management, and project design, which were not fully captured in the workload models.

At the same time, the performance of the academics was measured using criteria related to research outputs, teaching, and contribution to the university and broader community. These measures were similar across the faculty. However, internships require establishing and managing industry partnerships, which sometimes did not result in a measurable output. Upon reflection the researchers note the time spent on industry engagement had very little positive contribution to their careers. For example, in performance-based teaching and research, the industry collaborations were rarely acknowledged unless these associations resulted in a publishable case study, research or a report. In IFIs, this becomes more complex given that there can be commercialisation and patents associated with innovative projects. Hence, outcome measurements is an area that needs improvements in the future.

\section{Achieving industry-related objectives}

Students, with the support of academics, achieved the industry objectives by completing their projects. The final milestone of this process was presenting student findings to the specific organisation. Academics were invited by the industry for some of these student presentations. This event was similar to a session where consultants discuss their findings with the management. At these industry presentations, students received feedback from the senior members of the organisation and the academics who were present at these industry events. Additionally at the post internship de-briefing catch ups, industry partners gained invaluable feedback about their organisations. Figure 2 illustrates an example of the type of recommendations students developed.

Insert Figure 2 here 
As Figure 2 illustrates students in this case provided the means to realign current organisational strategy to suit new product development process. These kinds of feasible solutions were considered appropriate by the industry. These were highlighted in student performance evaluation conducted by the industry supervisor.

The performance evaluation was conducted separately from the industry presentations. Students met with their respective industry contact person/supervisor and obtained formal feedback about their performance. This evaluation was submitted to the teaching staff with students' final reflective report.

\section{Maintaining associations}

The student-university association was prominent as interns met subject coordinators at regular intervals. Students used subject consultation times to discuss their projects and these helped in translating theory into practice. Regular lectures that were the prerequisite subject of the IFI provided the basis for practical application. However, students' contact hours with the academics were limited and students required more access to academics (see section: feedback process).

The availability of the industry supervisors strengthened student-industry association. Industry supervisors provided formal inductions, clarified the project briefs and organisational cultural values, and helped students to fit in with the organisation:

We were apprehensive going into aged care, but our expectations were smashed. We walked into a truly innovative, forward-thinking business, and were supported at all times by a wonderful supervisor, XXX (Academic presentation: Students 1 and 2).

When students had limited access to their supervisor, some interns were assigned to other staff members while others formed working relationships with key staff in the workplace. However, students 4 and 5 found working within the manufacturing industry challenging, as they had to establish relationships before proceeding with the project. 
Industry-university associations were predominantly driven through informal engagements. The academics used their contacts in enhancing industry linkages in addition to the existing faculty business liaison manager's contacts with the industry. For example, one of the subject coordinators used connections with former students and contacts with networks outside of the university. In addition to informal engagement activities, industry stakeholders were invited for formal events at the university such as guest lectures. However, in this IFI, there were no formal agreements on intellectual rights. Hence, this might be an area which the program coordination team should focus on the future.

\section{Feedback process}

The feedback process was inbuilt within the program. The overall satisfaction of the program was measured through student achievements. For example, students 1 and 2 were proud of their presentation given to the industry partner:

The results [of the project] were phenomenal and the presentation day was one of the proudest days of our time as students (Academic presentation: Students 1 and 2).

Students provided feedback to academics to improve the communication process through their assignments. For example, students 1 and 2 suggested improving the communication between subject coordinators and the students. They also suggested ways of managing the IFI in parallel with the work placement program.

Students also provided feedback to the industry when they presented their product to the industry partner. The feedback was related to their assigned project rather than the internship experience. Students were focused on providing practical and feasible solutions (see example discussed earlier in Figure 2).

The industry partners provided feedback about the students, using a formal evaluation. This evaluation was more about student development and included 
constructive feedback and personal goals students should strive to achieve as well. Rather than a formal evaluation of the student presentations, the feedback was concentrated on developing students further. At the same time, academics coordinating the program obtained feedback from industry. The researchers either made industry visits for these discussions or had several telephone conversations to ensure that the industry partner needs were met. During these industry visits and telephone conversations, the academics coordinating the program had to have several difficult conversations that were at times challenging. For example, it was identified that one of the industry partners did not provide the relevant level of support to guide the innovation intern. There were several miscommunications that occurred about the expectations of the industry partner and the capabilities of the innovation intern. Nevertheless, the open and honest conversations and feedback helped in assessing the IFI and identifying improvements needed for future program delivery.

\section{Discussion, contributions and implications}

The aim of this paper was to understand how a Business faculty can design internships to enhance innovation skills among undergraduates. To this end, we developed a theoretical framework to facilitate the design, implementation and monitoring of IFIs by using available innovation and work-integrated literature and combining those with a stakeholder interdependency model of work-integrated learning. Using an illustrative case study at an Australian university, we explained the operationalisation of the theoretical framework within the university context. This section uses the framework and the case study to highlight study contributions to both theory and practice.

One of the main contributions is the proposed theoretical framework which combined innovation and work-integrated literature. Although innovation-related skills are required of future graduates, the literature review did not result in any available 
studies attempting to combine innovation with internships. As explained in the introduction, innovation is considered as an unintended positive outcome of the existing work placement programs. This paper combines these two streams of literature and provides an improved stakeholder interdependency model. The originality of this proposed framework mainly comes from the incorporation of innovation-related outcomes into the model. For example, the proposed framework identifies that industry should have a clear agenda for enhancing innovation, students need discovery skills in addition to professional skills, and universities need to fundamentally realign their internship programs to develop future-ready graduates. This requires both the university and the industry working closely and developing partnerships. The factors such as intellectual copyrights, which are usually not considered in professional internships, need to be discussed in IFI programs. Hence, this paper provides a theoretical foundation to develop, modify and refine work-integrated learning into a novel direction.

Second, this study provides suggestions to enhance innovative skills through internships - a novel way of addressing the skills required of future graduates. The study demonstrates that IFIs need to address both the innovation aspect as well as the work placement component. The programs need a clear shared aim among all the stakeholders with an inbuilt feedback process. The associations between each stakeholder need to be managed purposefully for the success of the program. By incorporating these into program design and implementation, this study suggests that graduate skills related to innovative thinking could be enhanced by modifying the existing work-integrated learning programs. Hence, this study contributes by proposing a novel mechanism of developing 'future-ready' graduates.

Third, the illustrative case study provides practical implications. Although the work placement component of the illustrated IFI is far better managed, refinement and improvements are required for innovation-related aspects in the future iteration of the program. This is expected, as unlike with the innovation aspects, the program 
coordinators and work placement team have years of experience in managing

professional work placements. This could happen in similar institutions in implementing IFIs, as universities have years of experience in managing work placements/internships. Similarly, the illustrated IFI case study demonstrates the need for improvements in the intellectual rights of the products developed, incorporation of IFI management into workload calculations and academic performance measures, and industry engagement. Others who want to initiate similar internships can use these findings and design programs accordingly.

There are several theoretical and practical ways to further develop IFI programs. First, the proposed stakeholder interdependency framework could be further developed theoretically by considering the role of the government and the overall policy environment. Patrick et al. (2008) found that the government is a key stakeholder of their model. Future studies could assess the ways which government policies enhance or hinder IFI programs, and ways which changes in policy priorities associated with leadership changes affect IFI programs, and incorporate these into the proposed stakeholder interdependency framework. Second, the illustrative case study highlights challenges in scaling-up IFIs. This illustrative case, for example, had only four projects with six students. However, identifying projects, providing feedback and coordinating IFIs could be challenging if there is an increase in student numbers. Hence, there may be a need for having external mentors or increasing the number of academics coordinating the IFI. Additionally, greater awareness is needed among the industry about the value of IFIs. Therefore, future programs could benefit by having awareness sessions for the industry highlighting the difference between conventional work placement programs and IFIs.

\section{References:}


Althaus, C. (2012), "Wireless broadband developments in Australia - An industry perspective", Telecommunications Journal of Australia, Vol. 62, No. 1, pp. $10.1-10.5$

Bowen, T. (2018), "Becoming professional: Examining how WIL students learn to construct and perform their professional identities", Studies in Higher Education, Vol. 43, No. 7, pp. 1148-1159.

Burdett, J. \& Barker, S. (2017), "University students in the workplace strategies for successful industry placement experiences", Development and Learning in Organizations: An International Journal, Vol. 31, No. 1, pp.15-18.

Cele, M. G. (2005), "Meeting the knowledge needs of the academy and industry: A case study of a partnership between a university and a large energy company in South Africa”, Industry and Higher Education, Vol. 19, No. 2, pp. 155-160.

Chang, H. (2008). Autoethnography as method. Walnut Creek, CA: Left Coast Press.

Chang, S. (2016), "Igniting creativity and innovation in engineering students: The case for technology and society courses in engineering curricula". Paper presented at the ASEE Annual Conference and Exposition, Conference Proceedings.

Chapleo, C., \& Simms, C. (2010). "Stakeholder analysis in higher education", Perspectives: Policy and Practice in Higher Education, Vol. 14, No. 1, pp. 1220.

Charmaz, K. (2006), Constructing grounded theory: A practical guide through qualitative analysis, London: Sage Publications.

Clark, L., Rowe, A., Cantori, A., Bilgin, A., \& Mukuria, V. (2016), “The power dynamics and politics of survey design: Measuring workload associated with teaching, administering and supporting work-integrated learning courses", Studies in Higher Education, Vol. 41, No. 6, pp. 1055-1073.

Collet, C., \& Wyatt, D. (2005), “"Bioneering" - Teaching biotechnology entrepreneurship at the undergraduate level", Education + Training, Vol. 47, No. 6, pp. 408-421.

de Villiers Scheepers, M. J., Barnes, R., Clements, M., \& Stubbs, A. J. (2018), "Preparing future-ready graduates through experiential entrepreneurship", Education + Training, Vol. 60, No. 4, pp. 303-317.

Dyer, J. H., Gregersen, H. B. and Christensen, C. M., (2009), "The innovator's DNA", Harvard Business Review, Vol. 87, No.12, pp.60-67.

Eesley, C. \& Miller, W. (2017), "Impact: Stanford University's economic impact”, Innovation and Entrepreneurship. Available at:

http://dx.doi.org/10.2139/ssrn.2227460

Eraut, M., Maillardet, F., Miller, C., Steadman, S., Ali, A., Blackman, C. \& Furner, J. (2004), "Learning in the first three years of postgraduate employment", Annual Report to ESRC/TLRP (Brighton, University of Sussex School of Education).

Evans, K., \& Guile, D. (2012), "Putting different forms of knowledge to work in practice", in J. Higgs, R. Barnett, S. Billett, M. Hutchings, \& F. Trede (Eds.), Practice-based education: Perspectives and strategies. Rotterdam: Sense Publishers. 
Ferkins, L. (2002), "Sporting best practice: An industry view of work placements", Asia-pacific Journal of Cooperative Education, Vol. 3, No. 2, pp. 29-34.

Ferrández-Berrueco, R., Kekale, T., \& Devins, D. (2016), “A framework for workbased learning: Basic pillars and the interactions between them", Higher Education, Skills and Work-based Learning, Vol. 6, No. 1, pp. 35-54.

Fitzgerald, B. K., Barkanic, S., Cardenas-Navia, I., Elzey, K., Hughes, D., Kashiri, E., \& Troyan, D. (2014), The BHEF National Higher Education and Workforce Initiative: A model for pathways to Baccalaureate attainment and high-skill careers in emerging fields. Industry and Higher Education, Vol. 28, No. 5, pp. 371-378.

Flores, M. (2016), Industry - university collaborative networks for new product development: The case of the Tenet Group in Iit Madras, India. IEEE International Technology Management Conference.

Fraser, S., Bishop, J., Rajarshi, R., Mancl, D., Ramming, J. C., \& Rivas, S. (2011), Industry-academic research partnerships. Companion to the 26th Annual ACM SIGPLAN Conference on Object-Oriented Programming, Systems, Languages, and Applications, OOPSLA 2011, part of SPLASH 2011, Portland, OR, USA, October 22 - 27, 2011

Galeano, N., Morales-Menendez, R., \& Cantú, F. J. (2012), "Developing research skills in undergraduate students through an internship program in research and innovation", International Journal of Engineering Education, Vol. 28, No. 1, pp. 48-56.

Gundry, L. K., Ofstein, L. F., \& Kickul, J. R. (2014). "Seeing around corners: How creativity skills in entrepreneurship education influence innovation in business", The International Journal of Management Education, Vol. 12, No. 3, pp. 529538.

Hardie, G., Almeida, S., \& Ross, P. (2018), Value of industry mentoring and resource commitment to the success of an undergraduate internship program: A case study from an Australian university, International Journal of Work-Integrated Learning, Vol. 19, pp. 155 - 168.

Hodge, P., Wright, S., Barraket, J., Scott, M., Melville, R., \& Richardson, S. (2011), "Revisiting 'how we learn' in academia: Practice-based learning exchanges in three Australian universities", Studies in Higher Education, Vol. 36, No. 2, pp. 167-183.

Holt, N.,L., (2003), "Representation, legitimation, and autoethnography: An autoethnographic writing story", International Journal of Qualitative Methods, Vol. 2, No. 1, pp. 18-28

Holyoak, L. (2013), “Are all internships beneficial learning experiences? An exploratory study", Education + Training, Vol. 55, No. 6, pp. 573-583.

Hoyle, J., \& Deschaine, M. E. (2016), “An interdisciplinary exploration of collegiate internships: Requirements for undergraduate and graduate programs", Education + Training, Vol. 58, No. 4, pp. 372-389.

Hoyle, J., \& Goffnett, S. (2013), “A stakeholder framework for designing and directing effective marketing internships", Journal for Advancement of Marketing Education, Vol. 21, No. 1, pp. 1-15. 
Hurn, K. M. (2016), "Joined up thinking? A review of the impact of a higher education and industry partnership on undergraduate product design students", Industry and Higher Education, Vol. 30, No. 2, pp. 129-139.

Hurst, J. L., \& Good, L. K. (2010), “A 20-year evolution of internships: Implications for retail interns, employers and educators", The International Review of Retail, Distribution and Consumer Research, Vol. 20, No. 1, pp. 175-186.

Hurst, J. L., Good, L. K., \& Gardner, P. (2012), "Conversion intentions of interns: What are the motivating factors?", Education + Training, Vol. 54, No. 6, pp. 504-522.

Jackson, D. (2015), "Employability skill development in work-integrated learning: Barriers and best practice", Studies in Higher Education, Vol. 40, No. 2, pp. 350-367.

Jackson, D., \& Chapman, E. (2012), "Non-technical competencies in undergraduate business degree programs: Australian and UK perspectives", Studies in Higher Education, Vol. 37, No. 5, pp. 541-567.

Khalil, O. E. M. (2015), "Students' experiences with the business internship program at Kuwait University", The International Journal of Management Education, Vol. 13, No. 3, pp. 202-217.

Kim, E. B., Kim, K., \& Bzullak, M. (2012), “A survey of internship programs for management undergraduates in AACSB-accredited institutions", International Journal of Educational Management, Vol. 26, No. 7, pp. 696-709.

Kinchin, I. M., \& Wiley, C. (2018). "Tracing pedagogic frailty in arts and humanities education: An autoethnographic perspective", Arts \& Humanities in Higher Education, Vol. 17, No. 2, pp. 241-264.

Luke, R. (2013). "Measuring innovation skills acquired by college and polytechnic students through applied research. Technology Innovation Management Review, Vol. 3, No.10, pp. 36-43.

Mil'Shtein, S. (2010), Developing student's innovation skills for globalized electronic industry. Paper presented at the 2010 IEEE Transforming Engineering Education: Creating Interdisciplinary Skills for Complex Global Environments.

Neill, N. T., \& Mulholland, G. E. (2003), "Student placement - structure, skills and esupport", Education + Training, Vol. 45, No. 2, pp. 89-99.

Patrick, C-J., Peach, D., Pocknee, C., Webb, F., Fletcher, M., \& Pretto, G. (2008). The WIL (Work Integrated Learning) report: A national scoping study [Final Report]: Queensland University of Technology. Retireved from: https://eprints.qut.edu.au/44065.

Petrillose, M. J., \& Montgomery, R. (1997), “An exploratory study of internship practices in hospitality education and industry's perception of the importance of internships in hospitality curriculum", Journal of Hospitality \& Tourism Education, Vol. 9, No. 4, pp. 46-51.

Prabhu, B. V., \& Aditya, A. K. (2016), "Success of student internship in engineering industry: A faculty perspective", Higher Education for the Future, Vol. 3, No. 2, pp. 164-182.

Procter, C. (2012), "Peer mentoring to secure student placements", Higher Education, Skills and Work-based Learning, Vol. 2, No. 2, pp. 121-131. 
Qi, G. Y., Shen, L. Y., Zeng, S. X., \& Jorge, O. J. (2010), "The drivers for contractors' green innovation: An industry perspective", Journal of Cleaner Production, Vol. 18, No. 14, pp. 1358-1365.

Quiñones, A. C., \& Humphrey, G. E. (2007), "Addressing the pharmacist shortage through a cooperative internship program for foreign pharmacy graduates", Journal of the American Pharmacists Association, Vol. 47, No. 2, pp. 191-196.

Renganathan, S., Karim, Z. A. B. A., \& Li, C. S. (2012), "Students' perception of industrial internship programme", Education + Training, Vol. 54, No. 2/3, pp. 180-191.

Rutherforda, T., \& Holmesb, J. (2008), "Engineering networks: University-industry networks in Southern Ontario automotive industry clusters", Cambridge Journal of Regions, Economy and Society, Vol. 1, No. 2, pp. 247-264.

Silva, P., Lopes, B., Costa, M., Melo, A. I., Dias, G. P., Brito, E., \& Seabra, D. (2018), "The million-dollar question: Can internships boost employment?", Studies in Higher Education, Vol. 43, No. 1, pp. 2-21.

Stahlke Wall, S. (2016). "Toward a moderate autoethnography", International Journal of Qualitative Methods, Vol. 15, No. 1, pp. 1-9.

Stanley, T. A. (2017), "Situated learning in accountancy: An employer perspective", Accounting Research Journal, Vol. 30, No. 3, pp. 265-282.

Starr-Glass, D. (2006), "Enhancing the Transformative Potential of Business Internships”, Managing Global Transitions, Vol. 4, No. 4, pp. 285-297.

Thatcher, J., Alao, H., Brown, C. J., \& Choudhary, S. (2016), "Enriching the values of micro and small business research projects: Co-creation service provision as perceived by academic, business and student", Studies in Higher Education, Vol. 41, No. 3, pp. 560-581.

Trahara, S. (2013), Autoethnographic journeys in learning and teaching in higher education, European Educational Research Journal, Vol.12, No. 3, pp. 367-375.

Trott, P. (2017), Innovation management and new product development. ( $\left.6^{\text {th }} \mathrm{ed}\right)$. Pearson, Harlow: United Kindom.

Tsai, H. H. (2011), The current status of tertiary students' problem solving abilities after one-year internship. Paper presented at the SEFI Annual Conference 2011.

Tudor, S., \& Mendez, R. (2014), "Lessons from covey: Win-win principles for university-employer engagement", Higher Education, Skills and Work-based Learning, Vol. 4, No. 3, pp. 213-227.

von der Heidt, T. (2018), “A scholarship approach to embedding creativity and sustainability in Marketing Principles curriculum", Australasian Marketing Journal (AMJ), Vol. 26, No. 2, pp. 99-115.

Walsh, F. D., \& Byrne, S. (2013), "Student placement service: An exploratory investigation of employer retention and a "Priority Partner" intervention", Education + Training, Vol. 55, No. 2, pp. 139-158.

Winkler, I. (2018). Doing autoethnography: Facing challenges, taking choices, accepting responsibilities, Qualitative Inquiry, Vol. 24, No. 4, pp. 239-247. 
World Economic Forum (2018), Future of jobs 2018, Retrieved from: http://www3.weforum.org/docs/WEF_Future_of_Jobs_2018.pdf.

Yildirim, N., \& Şimşek, K. (2015), Challenges in open innovation for ICT companies in technology development zones. Paper presented at the IAMOT 2015 - 24th International Association for Management of Technology Conference: Technology, Innovation and Management for Sustainable Growth, Proceedings.

Youtie, J., \& Shapira, P. (2008), "Building an innovation hub: A case study of the transformation of university roles in regional technological and economic development", Research Policy, Vol. 37, No. 8, pp. 1188-1204.

\section{Figure 1: Theoretical framework: Factors required for a successful innovation-focused}

\section{internship}

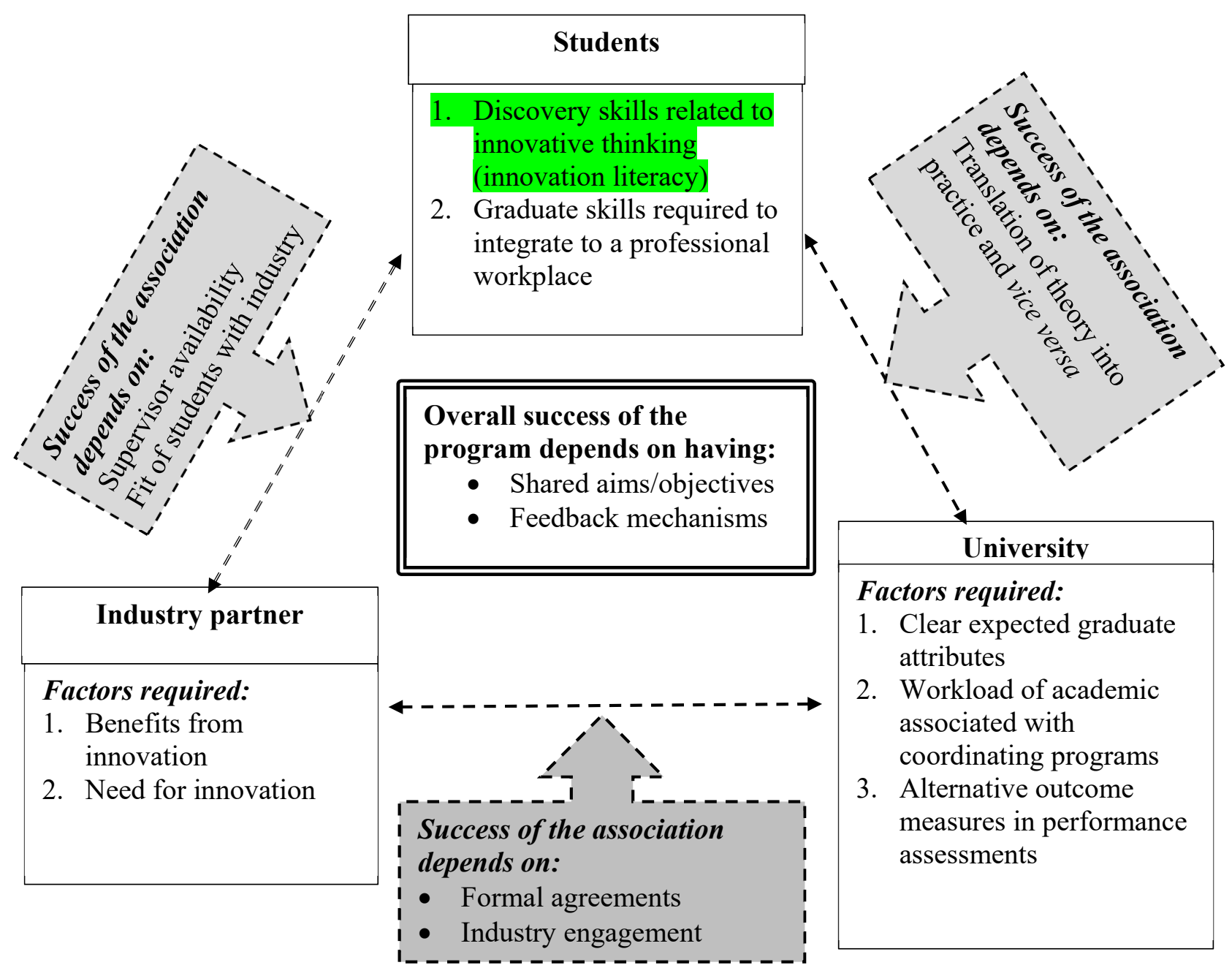


Table 1: Topics students studied in new product/service development

\begin{tabular}{ll}
\hline Category & Details \\
\hline Specific topics & The Strategic Elements of NPD \\
& The New Product Development Process \\
& Opportunity Identification \\
& Creativity and the NPD Process: Preparation and Alternatives \\
& Problem Based Ideation: Finding and Solving Customer Problems \\
& Concept Evaluation System \\
& Concept Testing \\
& Analytical Attribute Approaches: Perceptual Mapping \\
& Analytical Attribute Approaches: Trade-off Analysis and Qualitative \\
& Techniques \\
& Strategic Launch Planning \\
& Implementation of the Strategic Plan \\
& Market Testing \\
& Launch Management \\
& New Service Development \\
& Sustainable New Product and Service Delivery \\
& Traditional Opportunity Analysis vs Co-creation of Value: The World has \\
& Changed \\
& Rapid Prototyping and 3D printing \\
& Crowd Sourcing and Kick Starter \\
& Marketing's Working Relationships in NPD projects, Austran \\
& Social Media and Launch \\
& R\&D Outsourcing \\
& Open Innovation \\
\hline Special topics & \\
&
\end{tabular}


Protecting Intellectual Property and Patents

\begin{tabular}{ll}
\hline Innovation \& & Brainstorming \\
research skills & Focus group training and execution \\
training &
\end{tabular}

Table 2: Student projects and industries

\begin{tabular}{|c|c|c|c|c|}
\hline \multicolumn{3}{|c|}{ Student details } & \multicolumn{2}{|c|}{ Industry students' projects } \\
\hline & Gender & Student project & Industry & Activities \\
\hline & & & Type & \\
\hline Student 1 & Male & \multirow[t]{2}{*}{$\begin{array}{l}\text { Create a new model for } \\
\text { extra service delivery }\end{array}$} & $\begin{array}{l}\text { Aged care } \\
\text { service }\end{array}$ & \multirow{3}{*}{$\begin{array}{l}\text { Aged care and } \\
\text { retirement living } \\
\text { services }\end{array}$} \\
\hline Student 2 & Female & & & \\
\hline Student 3 & Male & $\begin{array}{l}\text { Develop and market a } \\
\text { grant program to boost } \\
\text { innovative idea } \\
\text { generation among } \\
\text { internal staff }\end{array}$ & & \\
\hline Student 4 & Male & \multirow{2}{*}{$\begin{array}{l}\text { Develop an innovative } \\
\text { approach for social } \\
\text { media and web-content } \\
\text { management }\end{array}$} & \multirow{2}{*}{$\begin{array}{l}\text { Manufacturing } \\
\text { company }\end{array}$} & \multirow{2}{*}{$\begin{array}{l}\text { Production of fluid } \\
\text { management, transfer } \\
\text { and lubrication } \\
\text { equipment }\end{array}$} \\
\hline Student 5 & Female & & & \\
\hline Student 6 & Female & $\begin{array}{l}\text { Create a marketing plan } \\
\text { to assist in transforming } \\
\text { product-based to a }\end{array}$ & $\begin{array}{l}\text { Manufacturing } \\
\text { and }\end{array}$ & $\begin{array}{l}\text { Production and } \\
\text { distribution of } \\
\text { commercial and }\end{array}$ \\
\hline
\end{tabular}




$\begin{array}{lll}\text { service-based business } & \text { distribution } & \text { industrial plumbing } \\ \text { model } & \text { company } & \text { and safety equipment }\end{array}$

Figure 2: An example of the recommendations provided by students

\begin{tabular}{|c|c|c|}
\hline Element of NPD Process & Star rating & Proposed realignment strategy \\
\hline $\begin{array}{l}\text { Establishing new product goals and } \\
\text { priorities }\end{array}$ & $\star \star \star$ & Increased meetings in early NPD process \\
\hline $\begin{array}{l}\text { Establishing product development } \\
\text { schedules }\end{array}$ & $\star \star \star \star \star \star$ & Maintain current Gant chart practice \\
\hline $\begin{array}{l}\text { Finding commercial applications of } \\
\text { R\&Ds new product ideas of } \\
\text { technologies }\end{array}$ & $\star \star \star$ & More market research (focus group, surveys) \\
\hline Generating new product ideas & $\star$ & $\begin{array}{l}\text { Innovation meetings with representatives from each } \\
\text { department bringing varying perspectives }\end{array}$ \\
\hline Analysing customer needs & $\star \star$ & More market research (focus group, surveys) \\
\hline Meeting customer requirements & $\star \star \star \star$ & $\begin{array}{l}\text { Newly created digital marketing segment, reflecting } \\
\text { changing market needs }\end{array}$ \\
\hline
\end{tabular}

\begin{tabular}{|c|c|c|}
\hline Element of NPD Process & Star rating & Proposed realignment strategy \\
\hline $\begin{array}{l}\text { Developing new products } \\
\text { according to market's needs }\end{array}$ & $\star \star$ & $\begin{array}{l}\text { More market research and increased digital } \\
\text { presence }\end{array}$ \\
\hline $\begin{array}{l}\text { Modifying products according to } \\
\text { marketing's recommendations }\end{array}$ & $\star \star \star$ & $\begin{array}{l}\text { (Mostly done with development of new technology } \\
\text { to make products stronger, faster etc.) }\end{array}$ \\
\hline Screening ideas & $\star \star \star$ & $\begin{array}{l}\text { Run ideas by marketing department before pursuing } \\
\text { product development in engineering }\end{array}$ \\
\hline Test marketing results & $\star \star$ & Incorporate consumer focus group early in NPD \\
\hline $\begin{array}{l}\text { Feedback regarding product } \\
\text { performance }\end{array}$ & $\star \star \star \star \star$ & Maintain Google Analytics analysis \\
\hline Information on competitors' moves & $\star \star \star \star \star$ & $\begin{array}{l}\text { Increased competitor research and comparative } \\
\text { analysis }\end{array}$ \\
\hline
\end{tabular}




\section{RECOMMENDATIONS}

Utilising Griffin and Hauser (1996)'s framework, we developed at guide for integrating mechanisms at XXX.

\begin{tabular}{|c|c|c|c|c|}
\hline $\begin{array}{l}\text { Integrating } \\
\text { Mechanism }\end{array}$ & $\begin{array}{l}\text { Barriers } \\
\text { Overcome }\end{array}$ & Aspect of Integration & $\begin{array}{l}\text { Uncertainty } \\
\text { Reduced }\end{array}$ & Outcomes Affected \\
\hline $\begin{array}{l}\text { Designated meeting } \\
\text { space/ work room for } \\
\text { marketing and R\&D }\end{array}$ & Physical separation & - Information amount & - & $\begin{array}{l}\text { Success } \\
\text { Time }\end{array}$ \\
\hline Liaison group & $\begin{array}{l}\text { Expertise and skill } \\
\text { separation }\end{array}$ & $\begin{array}{l}\text { - Information } \\
\text { utilization } \\
\text { - Resolve conflict }\end{array}$ & $\begin{array}{l}\text { Technology and } \\
\text { skill }\end{array}$ & $\begin{array}{l}\text { Success } \\
\text { Time }\end{array}$ \\
\hline $\begin{array}{l}\text { Consumer focus groups } \\
\text { in early NPD }\end{array}$ & Physical separation & - Information access & Market & $\begin{array}{l}\text { Success } \\
\text { Profits }\end{array}$ \\
\hline
\end{tabular}

